\title{
Virtuální realita v porodní asistenci jako nefarmakologická metoda
}

\section{Virtual reality in obstetrics as a non pharmacological method}

\author{
Puhlová Eva ${ }^{1}$, Binder Tomáš ${ }^{2}$ \\ ${ }^{1}$ Fakulta zdravotnických studií, Univerzita Jana Evangelisty Purkyně v Ústí nad Labem, \\ Katedra Porodní asistence a specifických disciplín, Česká republika \\ ${ }^{2}$ Masarykova nemocnice v Ústí nad Labem, Gynekologicko-porodnická klinika, \\ Ústí nad Labem, Česká republika
}

\begin{abstract}
ABSTRAKT
Východiska: Virtuální realita (VR) je nová technologie, která se používá při lékařských procedurách a prokázala se jako platná nefarmakologická metoda $\mathrm{k}$ léčbě bolesti a úzkosti. Tato modalita je $\mathrm{v}$ medicíně nová a $\mathrm{v}$ procesu porodu by se mohla stát potenciálně novou a účinnou nefarmakologickou metodou, která by zajistila zlepšení v oblasti zvládání úzkosti a porodní bolesti při porodu $(1,2)$. Předložený př́spěvek obsahuje deskripci a analytickou práci s výsledky na téma virtuální reality v porodní asistenci.

Cíl: Hlavním cílem př́spěvku byla literární review, analýza literárních zdrojů zabývající se využitím virtuální reality jako nefarmakologické metody při péči o ženy s porodní bolestí.

Metodika: Literární review a kvalitativní studie, byly vyhledány systematickou rešerší v elektronických databázích Pubmed, Web of Science, CINAHL, Cochrane database a samostatně i časopis Journal of Midwifery. Byla stanovena klíčová slova: nefarmakologická metoda, porodní bolest a virtuální realita. Rovněž byla stanovena kritéria vyhledávacího období na prosinec 2019 - červen 2020. Články byly vyhledány v anglickém jazyce. Získané studie byly tř́děny podle doporučení Prisma.

Výsledky: Celkem bylo vyhledáno a porovnáno 6 studií z Ameriky, Iránu a Itálie. V České republice dosud neproběhly žádné studie na dané téma. Výsledky studií poukázaly na pozitivní vliv využití virtuální reality jako nefarmakologické metody v péči o ženy s porodní bolestí. Ženy za využití virtuální reality při porodu udávaly nižší VAS (vizuální analogová škála) a NRS (Nutritional Risk Screening) skóre a celkově lépe zvládaly průběh porodu. Závěr: Virtuální realita $\mathrm{v}$ porodnictví by mohla být jednou $\mathrm{z}$ dalších nefarmakologických metod pomáhající ženám zvládat porodní bolesti, strach a úzkost při porodu. Tato nová metoda by mohla změnit př́stup v oblasti poskytovaní zdravotní péče o rodící ženy s porodní bolestí.
\end{abstract}

\section{ABSTRACT}

Background: Virtual Reality (VR) is a new technology used in medical procedures and has proven to be a valid non-pharmacological method for the treatment of pain and anxiety. This modality is new in medicine and very modern in the birth process and could become a potentially effective non-pharmacological method for improving the management of labor pain and anxiety during childbirth $(1,2)$. The presented paper contains a description and analytical work with the results on the topic of virtual reality in midwifery.

Aim: The main aim of the paper was a literary review, an analysis of literary sources dealing with the use of virtual reality as a non-pharmacological method in the care of women with labor pain.

Methods: Literary review and aqualitative studies were searched by systematic search in electronic databases Pubmed, Web of Science, CINAHL, Cochrane database and Journal of Midwifery. Defined kewords: non-pharmacological method, labor pain, virtual reality. Established criteria was period December 2019 - June 2020. Articles were searched in English. The obtained studies were classified according to Prisma recommendations.

Results: A total of 6 studies from the Americas, Iran and Italy were searched and compared. No studies on this topic have been carried out in the Czech Republic so far. The results of the studies showed a positive effect of the use of virtual reality as a non-pharmacological method in the care of women with labor pain. Using virtual reality during childbirth, women reported lower VAS, NRS scores and better managed the course of childbirth.

Conclusions: Virtual reality in obstetrics could be one of the other non-pharmacological methods helping women to manage labor pains, fears, anxiety during childbirth. The new method could change the approach in the care provided for women with labor in childbirth. 
KLÍČOVÁ SLOVA

Nefarmakologická metoda, Porodní asistence, Porodní bolest, Virtuální realita

KEY WORDS

Non-pharmacological method, Midwifery, Labor pain, Virtual reality

\section{ÚVOD}

Porodní bolest je specifický porodnický fenomén, lišící se od klasických bolestí. Její vnímání a prožívání je velmi individuální (3). Porodní bolest je navíc ovlivňována mnoha faktory, proto je velmi obtížné posoudit její individualitu. $Z$ toho důvodu je náročná jak diagnostika, tak péče o ženy s porodní bolestí (4). Málek (5) považuje za důležité při péči o ženy s porodní bolestí zajištění maximální psychické a fyzické pohody ženy. K pochopení porodní bolesti je důležité znát komplexně aspekty vzniku porodní bolesti, její diagnostiku a možnosti pomoci od bolesti. Žena by měla mít možnost výběru metody tišení porodní bolesti, která jí navíc v danou situaci bude vyhovovat co nejvíce. Zvolená metoda by neměla ovlivňovat fyzický, psychický, emoční stav ženy, ohrozit plod a narušit zážitek a zkušenost s porodem (2).

Cílem moderního porodnictví, by tak mělo být naučit ženy přijmout porod a porodní bolest jako přirozený proces a naučit ženy adaptovat se a pracovat s porodní bolestí (2), odstranit u žen strach z porodu a vyhnout se tak s negativními zkušenostmi při porodu. K tomu slouží různé metody (6). Metody pomáhající ženám od porodní bolesti a můžeme je dělit na nefarmakologické a farmakologické. Tyto metody mohou být následně použity postupně nebo i v kombinaci. Nefarmakologické metody pomáhají ženám spíše vyrovnat se s bolestí při porodu, adaptovat se na ni a zvládat ji, než aby ji př́mo zmírnily či dokonce odstranily. Farmakologické metody naopak zmírňují bolest, ale nemusí zmírňovat úzkost a strach $\mathrm{z}$ porodu nebo negativní prožívání ženy. $\mathrm{V}$ dnešní době však výsledků studií jako $(2,7,8,9)$ poukazují spíše na vyšší efektivitu nefarmakologických intervencí. Z tohoto důvodu, při péči o ženu s porodní bolestí, by se mělo postupovat nejprve od nefarmakologických metod po farmakologické. Navíc využití nefarmakologických metod podporuje více prrirozený porod, čímž se následně snižují negativní výsledky porodu (2). Mezi nejznámější a nejvyužívanější nefarmakologické metody jsou dnes řazeny hlavně hydroterapie, aromaterapie, polohování, masáž a jiné (3). Avšak dochází k vývoji a využití nových nefarmakologických metod, jež pomáhají zvládat porodní bolest.
Mezi nejnovější techniku můžeme zařadit i virtuální realitu VR, která přitahuje stále více pozornost $\mathrm{v}$ různých oblastech medicíny. Virtuální realita spočivá ve využití propojení počítačové a zobrazovací technologie, kdy dochází $\mathrm{k}$ promítání př́ijemného simulovaného obrazu prostředí, nap̌r. prrírody. Počítačová simulace realisticky vyhlížejícího iluzivního $3 \mathrm{D}$ prostředí je následně vnímaná jedincem jako prostředí reálné. Vytvořenou projekcí a vizualizací do imaginárního prostředí je jedinec izolován od „skutečného světa - nemocničního prostředí a situace“, což má následně vliv na psychický a fyzický stav pacienta, což vede ke snížení úzkosti, strachu, zlepšení fyziologických funkcí a vnímání bolesti. Tato myšlenka může být využívána právě i v situaci porodního prostř̌edí u rodící ženy s porodní bolestí. Autor udává, že virtuální technologie si za pár let získá samostatné místo $\mathrm{v}$ péči o rodící ženy s porodní bolestí (1).

\section{PROBLÉM LITERÁRNÍHO PŘEHLEDU}

Cílem bylo vyhledat a analyzovat studie zaměřené na využití virtuální reality jako nefarmakologické metody při péči o rodící ženy s porodní bolestí. Součástí tohoto cíle bylo na podkladě vyhledaných studií zpracovat přehledovou práci na danou problematiku pro potřeby dalšího šetření v naší klinické praxi.

\section{POPIS REŠERŠNÍ STRATEGIE \\ Výběrová kritéria}

K analýze byly vyhledány kvalitativní a kvantitativní studie zabývající se problematikou virtuální reality $\mathrm{v}$ porodní asistenci a porodní bolestí. Pro literární přehled byla stanovena výběrová kritéria: anglický jazyk, plný text článku, recenzované články, odborné studie. Časové rozpětí pro vyhledávání článků stanoveno od roku 2019 až do roku 2020.

\section{Zdroje}

Pro získání relevantních zdrojů byly využity elektronické informační databáze CINAHL, PubMed, Web of Science a samostatně i časopis Journal of Midwifery. Vyhledávání relevantních článků probíhalo od prosince 2019 do června 2020 a posléze proběhlo jejich samotné zpracování. 


\section{Vyhledávání}

V rámci rešeršní strategie byla definována vyhledávací slova virtuální realita, nefarmakologická metoda, porodní bolest a porod. Využili jsme Boolovské operátory „OR” a „AND”, dále ohraničení klíčových slov uvozovkami „virtual reality in labour“, které zajistilo vyhledávání tohoto konkrétního slovního spojení. $\mathrm{Z}$ rešerše byly vyřazeny články neobsahující klíčová slova, články vydané $\mathrm{v}$ jiném jazyce než anglickém, knihy nebo recenze knih. U publikací, které obsahovaly uvedená klíčová slova, byla provedena obsahová analýza.

Vyřazeny byly články nesplňující uvedená kritéria, abstrakta, články nerecenzovaných časopisů a dokumenty, které se nezabývaly objasněním pojmu. Použili jsme postupné vyřazování studií podle doporučení PRISMA (Schéma 1). Z celkového počtu 20 záznamů splňovalo zvolená kritéria pouze 6 článků. Vyřazeny byly rovněž články, které popisovaly kvantitativní studie.

\section{Výběr a analýza studií}

Pro konečnou analýzu byly zvoleny kvalitativní studie. Relevantní studie byly kriticky pročteny, detailně analyzovány a popsány, nicméně metodologická kvalita studií nebyla posuzována. Výsledné poznatky byly zapracovány do přehledu. Př́nosem práce je seznámení a rozšírení vědomostí v oblasti využití nefarmakologických metod při porodu a porodní bolestí. Dále může pomoci i při využití virtuální reality jako moderní technologie $\mathrm{v}$ porodnictví.

\section{TEXT LITERÁRNÍHO PŘEHLEDU Výsledky}

Bylo porovnáno 6 studií z Ameriky, Iránu a Itálie, jež se zabývaly kvalitativní metodologickou perspektivou $\mathrm{v}$ př́stupu využití virtuální reality jako nefarmakologické metody při léčbě porodní bolestí. Analýza dat byla použita pro syntézu výsledků v tomto přehledovém článku.

Ze studií $(10,11,1,12,13)$ vyplývá pozitivní vliv virtuální reality jako nefarmakologické metody $\mathrm{v}$ péči o ženy s porodní bolestí v I. době porodní, ale i při ošetření epiziotomie a v poporodním období. Ženy při využití této metody hodnotily pozitivněji zvládání samotného porodu, porodní bolesti a byly více spokojeny s péćí porodní asistentky a zdravotnického personálu. Data ukazují, že významným faktorem podílejícím se na rozvoji porodní bolesti je strach a úzkost (10).

Hlavním efektem virtuální reality při péči o rodící ženu je právě účinek na kognitivní funkce ženy, což vede ke snížení strachu a úzkosti z probíhajícího porodu. To vše má pozitivní vliv na porodní bolest a celkově lepší zvládání průběhu porodu. Ze studií je patrné, že ženy, jež využily metodu VR při porodu, hodnotí porodní bolest jako lépe snesitelnou, mají nižší skóre bolesti (hodnoceno VAS, NRS) oproti ženám,

Schéma 1 Proces výběru a třídění studií zaměřených na využití VR

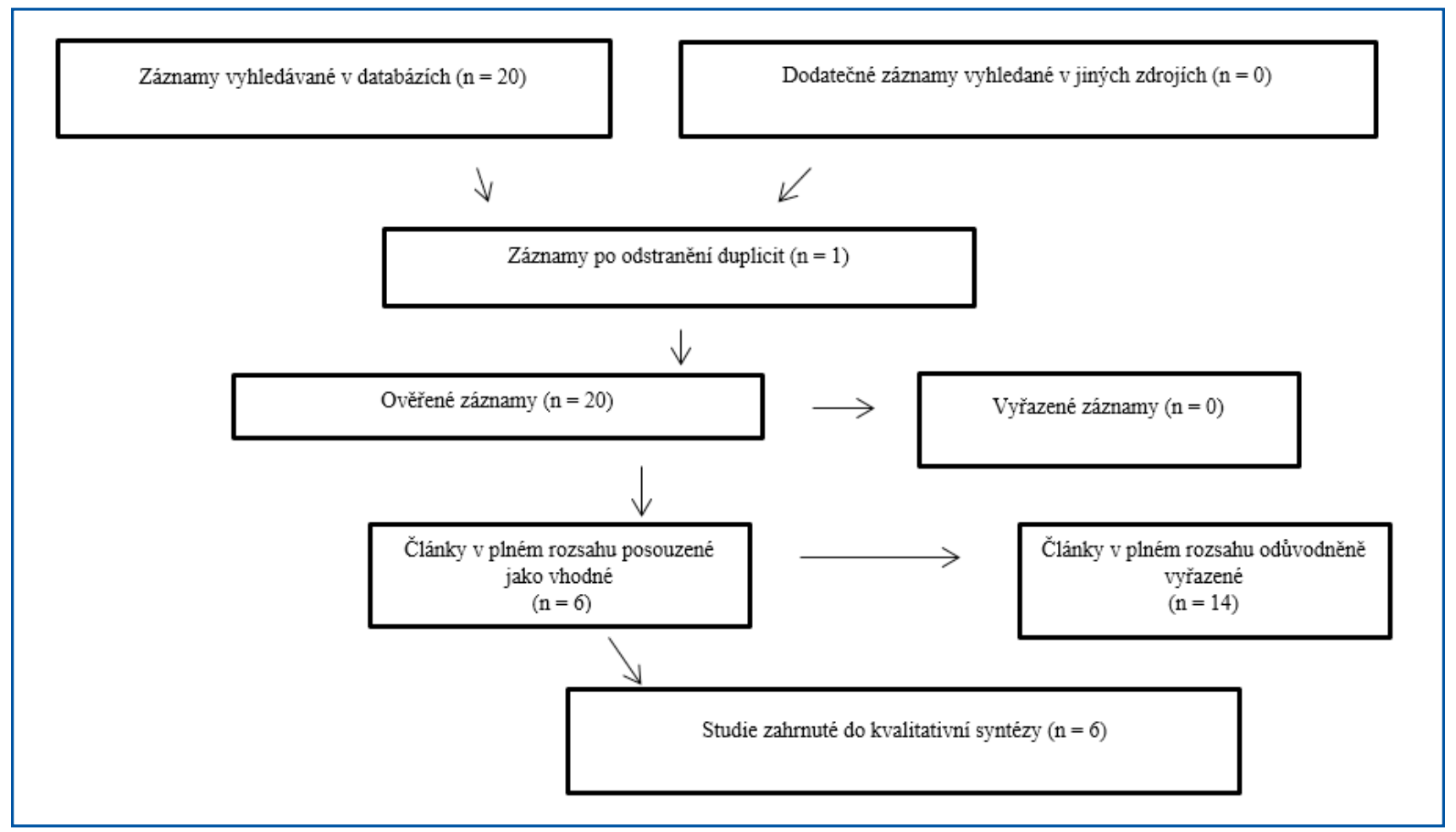


které využili v průběhu porodu farmakologických metody pomáhající od bolesti. Všechny výsledky studií
(Tabulka 1) poukázaly na pozitivní význam VR jako nefarmakologické metody prri porodu.

Tabulka 1 Přehled studií: Využití VR jako nefarmakologické metody při péči o ženu s porodní bolestí

\begin{tabular}{|c|c|c|c|}
\hline Autor/rok/země & Hypotézy/cíle & $\begin{array}{l}\text { Druh výzkumného přístupu/ } \\
\text { metodika/typ respondentů }\end{array}$ & Výsledky/zjištění \\
\hline $\begin{array}{l}\text { Koyyalamudi et al., } \\
2016 \\
\text { Amerika }\end{array}$ & $\begin{array}{l}\text { Popsat aktuální } \\
\text { a nejnovější trendy } \\
\text { v léčbě porodní } \\
\text { bolesti. }\end{array}$ & $\begin{array}{l}\text { Kvalitativní studie, využívající } \\
\text { fenomenologický prístup. } \\
\text { Systematický přehledový článek. }\end{array}$ & $\begin{array}{l}\text { Výsledky popisuji jednotlivé moderní } \\
\text { nefarmakologické metody, ale i jejich } \\
\text { pozitivní vliv při péči o ženu s porodní } \\
\text { bolestí. }\end{array}$ \\
\hline $\begin{array}{l}\text { Ebrahimzadeh et al., } \\
2015 \\
\text { Iran }\end{array}$ & $\begin{array}{l}\text { Popsat využití } \\
\text { VR při ošetření } \\
\text { epiziotomie jako } \\
\text { nefarmakologické } \\
\text { metody při bolesti. }\end{array}$ & $\begin{array}{l}\text { Kvalitativní studie. Klinickým } \\
\text { hodnocením bylo posouzeno } \\
30 \text { primipar. V období května } \\
\text { až července } 2012 \text {. Skupina žen } \\
\text { byla náhodně rozdělena do dvou } \\
\text { stejných skupin. Intervenční skupina } \\
\text { podstoupila léčbu VR (videokamery } \\
\text { a infiltrace } 5 \mathrm{ml} \text { roztoku } \\
2 \% \text { lidokainu) a kontrolní skupina } \\
\text { dostala pouze lokální infiltraci. } \\
\text { Bolest byla hodnocena pomocí } \\
\text { číselné stupnice (0-100) před, během } \\
\text { a po ošetření epiziotomie. }\end{array}$ & $\begin{array}{l}\text { Výsledky poukazují na efektivitu } \\
\text { virtuální reality jako nefarmakologické } \\
\text { metody k snižování bolesti při ošetření } \\
\text { epiziotomie. Byl potvrzen statistický } \\
\text { rozdíl mezi intervenční a kontrolní } \\
\text { skupinou při hodnocení skóre bolesti } \\
(\mathrm{p}=0,038) \text {. }\end{array}$ \\
\hline $\begin{array}{l}\text { Frey et al., } 2019 \\
\text { Amerika }\end{array}$ & $\begin{array}{l}\text { Posoudit využití } \\
\text { VR v péči o ženy } \\
\text { s porodní bolestí. }\end{array}$ & $\begin{array}{l}\text { Kvalitativní studie. Kontrolovaná } \\
\text { pilotní studie. Prospektivní } \\
\text { randomizovaná kontrolní studie. } \\
\text { Období listopad } 2016 \text { - duben } 2017 . \\
\text { Bylo hodnoceno } 28 \text { žen v průběhu } \\
\text { I. doby porodní s pravidelnou } \\
\text { děložní činností a porodní bolestí za } \\
\text { využití VR jako nefarmakologické } \\
\text { metody. Skóre bolesti bylo } \\
\text { posuzováno dotazníkem pro } \\
\text { hodnocení bolesti NRS. }\end{array}$ & $\begin{array}{l}\text { Pilotní stude zjistila, že je možné } \\
\text { využít zážitek z VR ke snížení bolesti } \\
\text { a úzkosti během první fáze porodu. } \\
\text { Primární výsledek pro skóre nejhorší } \\
\text { intenzity bolesti (smyslová bolest) } \\
\text { byl signifikantně nižší ve stavu VR, } \\
\text { s podobným poklesem pozorovaným } \\
\text { u sekundárních výsledků hlášených } \\
\text { skóre afektivní a kognitivní bolesti. }\end{array}$ \\
\hline $\begin{array}{l}\text { Cowles et al., } 2018 \\
\text { Amerika }\end{array}$ & $\begin{array}{l}\text { Zhodnotit } \\
\text { využití VR jako } \\
\text { nefarmakologické } \\
\text { metody k léčbě } \\
\text { porodní bolesti, } \\
\text { úzkosti a strachu } \\
\text { z porodu. }\end{array}$ & $\begin{array}{l}\text { Kvalitativní randomizovaná } \\
\text { kontrolovaná pilotní studie, } \\
\text { k prŕípravě dlouhodobé studie. Byly } \\
\text { sledovány dvě skupiny žen v průběhu } \\
\text { I. doby porodní. Ženy s využitím VR } \\
\text { a kontrolní skupina. Celkem } 20 \text { žen, } \\
\text { u kterých bylo posuzováno skóre } \\
\text { bolesti každé } 4 \text { hodiny pomocí VAS } \\
\text { a NRS (1-10). }\end{array}$ & $\begin{array}{l}\text { Studie udává, že se VR prokázala jako } \\
\text { platná nefarmakologická metoda k léčbě } \\
\text { porodní bolesti, úzkosti a strachu } \\
\text { z porodu. } \\
\text { Byl prokázán rozdíl v hodnocení skóre } \\
\text { porodní bolesti mezi kontrolní }(\mathrm{p}=3,46) \\
\text { a výzkumnou skupinou žen }(\mathrm{p}=2,74)\end{array}$ \\
\hline $\begin{array}{l}\text { Montano, et al., } 2011 \\
\text { Amerika }\end{array}$ & $\begin{array}{l}\text { Posoudit využití } \\
\text { VR v managementu } \\
\text { v různých oblastech } \\
\text { medicíny. }\end{array}$ & $\begin{array}{l}\text { Kvalitativní popisná studie. } \\
\text { Přehledový článek shrnující } \\
\text { využití VR v medicíně, mimo jiné } \\
\text { i v porodní asistenci. Bylo vyhledáno } \\
10 \text { studií za období roku } 2011 .\end{array}$ & $\begin{array}{l}\text { Výsledky poukazují na experimentální } \\
\text { možnosti využití VR v managementu } \\
\text { péče o pacienty jak s akutní, tak } \\
\text { chronickou bolestí v různých oblastech } \\
\text { medicíny. }\end{array}$ \\
\hline $\begin{array}{l}\text { Triberti et al., } 2014 \\
\text { Itálie }\end{array}$ & $\begin{array}{l}\text { Posoudit } \\
\text { využití VR jako } \\
\text { nefarmakologickou } \\
\text { metodu při léčbě } \\
\text { porodní bolesti, } \\
\text { psychologické faktory } \\
\text { porodní bolesti } \\
\text { a efektivitu VR. }\end{array}$ & $\begin{array}{l}\text { Kvalitativní systematická přehledová } \\
\text { studie. Analýza literárních zdrojů } \\
\text { zaměřených na efektivitu VR jako } \\
\text { nefarmakologické metody při } \\
\text { léčbě porodní bolesti a posouzení } \\
\text { psychologických faktorů ovlivňující } \\
\text { porodní bolesti. Bylo vyhledáno } \\
\text { celkem } 11 \text { studií v období roku } 2014 \text {. }\end{array}$ & $\begin{array}{l}\text { Prožívání porodní bolesti je ovlivňováno } \\
\text { mnoha psychologickými faktory, krom } \\
\text { jiného z velké části tvořená z prostředí. } \\
\text { Přehledová studie poukazuje na } \\
\text { efektivitu VR při ponoření do prostředí } \\
\text { VR k léčbě porodní bolesti, jako účinný } \\
\text { nástroj k rozptýlení vnímání této bolesti. }\end{array}$ \\
\hline
\end{tabular}




\section{VÝSTUPY}

\section{Diskuze}

Porod je aktivní děj, jež je charakterizován pravidelnými, bolestivými kontrakcemi děložní svaloviny, jež se projevuje výsledně prožitkem porodní bolesti. Porodní bolest je specifický fenomén a je řazena do skupiny aktivní bolesti, ačkoli spadá dle etiologie a projevů na pomezí ostatních typů bolestí. Porodní bolest je ovlivněna řadou psychosociálních a psychologických faktorů, jako jsou osobnostní rysy, kulturní zvyklosti, fyzický stav ženy a dalšími faktory, čímž je tak charakteristická. Jedním $\mathrm{z}$ dalších nejvíce působících faktorů je vliv prostředí, do kterého spadá jak samotné prostř̌edí, ve kterém žena rodí, ale i sociální prostředí. Na podkladě znalosti etiologie a dalších faktorů (jako například porodní prostředí, zdravotnický personál) podílejících se na vnímání a prožívání porodní bolesti, je možné se zaměřit na jejich eliminaci. K tomu slouží různé nefarmakologické metody pomáhající zvládat porodní bolest a odstranit některé nepř́ijemné faktory (např́íklad aromaterapie, muzikoterapie, vizualizace) $(3,5)$. Jako nově využitelnou metodu při zvládání porodní bolesti u žen můžeme řadit i tzv. kognitivně-behaviorální metodu VR.

Tato metoda funguje na principu ponoření se do počítačově generovaného trojrozměrného virtuálního prostředí, což má vliv na centrální nervovou soustavu a přenos vjemu bolesti, a proto mění výsledný prožitek z porodní bolesti. $\mathrm{V}$ našem př́ípadě se jedná o vytvoření virtuálního prostředí, které je pro ženu v průběhu porodu př́ijemné a snaží se odstranit, či eliminovat myšlenky na porodní proces, strach z porodní bolesti vlivem na kognitivní funkce centrální nervové soustavy (př́roda, relaxační místnost). Metoda pracuje i na podkladě psychologické intervence imaginace, tzn. schopnosti člověka vyvolávat v mysli libé představy, myšlenky, změny vnímání a proživání situací $(1,12)$.

Cílem předloženého sdělení bylo posoudit literární studie zabývající se využitím virtuální reality jako nefarmakologické metody při péči o ženy s porodní bolestí v porodní asistenci.

Zjištěné výsledky z literární review $(10,1,12,13$, 14) ukazují, že virtuální realita může být potencionálně efektivní jako nefarmakologická př̀ péči o ženy s porodní bolestí.

Bylo zjištěno, že VR jako nová metoda ovlivňuje pozitivně prožívání a vnímání porodní bolesti a snižuje hladinu bolesti. Podílí se na snižování strachu z porodu a negativních myšlenek z porodního procesu, což je pro zvládání porodní bolesti klíčové. Pokud dochází k eliminaci strachu - úzkosti, snižuje se vyplavování stresových hormonů a tím se snižuje tenze svalů $\mathrm{v}$ oblasti pánevního dna, podílející se na etiologii právě porodní bolesti. Ženy ve studiích Freye (1) a Cowlese (10) poukazovaly na nižší skóre bolesti, které bylo hodnoceno hodnotícími technikami VAS a NRS. Průměrné skóre bolesti bylo u žen před použitím VR $(2,74)$. Po použití VR se skóre bolesti snízilo na $(2,35)$. Respondentky celkově kladně hodnotily využití nové metody (1). Ve studii Cowlese (10) až $77 \%$ žen subjektivně udávaly, že při použití VR během porodu lépe vnímaly porodní bolest a při dalším porodu by chtěly znovu VR využít. Pro $33 \%$ byla VR užitečná hlavně v latentní fázi porodu. Důvodem bylo, že v aktivní fázi porodu vnímaly ženy porodní bolest intenzivněji. Studie Ebrahimzadeha (11) potvrdila stejné výsledky v péči o rodící ženy jako studie Freye (1) a Cowlese (10). Krom toho studie poukázala na efekt VR při ošetření epiziotomie. Díky aplikaci VR došlo u žen $\mathrm{k}$ audiovizuálnímu rozptýlení od úzkosti a bolesti spojené s ošetřením epiziotomie. Montano (14) sledoval efekt VR komplexně v medicínských oborech, kde hlavní využití této metody bylo zjištěno právě v porodnictví a v gynekologii. Její využití našlo místo nejen v léčbě porodní bolesti, ale i další akutní bolesti jako např́klad u žen po gynekologických výkonech, při zavádění nitroděložního tělíska a při ošetření sutur. Jeho studie však poukázala i na možné vedlejší účinky VR, jako jsou bolest hlavy, nevolnost, které je potřeba vzít $\mathrm{v}$ úvahu při dalších zkoumáních. Navíc konstatuje, že při využití VR během léčby bolesti nejsou zahrnuty i psychosociální a kulturní faktory, jež se podílí na prožívání a zvládání bolesti, což platí i pro porodní bolest.

Autoři na podkladě dat došli $\mathrm{k}$ závěru, že virtuální realita může být potencionálně účinná metoda při péči o ženy s porodní bolestí a s úzkostí během porodu. Avšak je potřeba provést další výzkum především v klinické praxi.

$\mathrm{V}$ dnešní době mnohé ženy čelí problému, že při lékařsky vedených porodech se zř́dka využívají nefarmakologické metody ulevující od bolesti. Trendem je vyšší požadavek na alternativní techniky pomáhající od bolesti, jako je právě VR (15), které se podílí na lepším zvládání, prožívání a vnímání porodní bolesti. To vede nejenom $k$ lepší spolupráci rodičky a porodní asistentky, ale také $\mathrm{k}$ prrirozenému porodu, eliminaci rizik komplikací v průběhu porodu a $\mathrm{v}$ poporodním období a rovněž ke snižování negativních zkušeností se samotným porodem (16). Tyto poznatky by se mohly odrazit $v$ argumentech o nutnosti znalosti etiologie, managementu porodní bolesti a různých alternativních a moderních metodách, které pomáhají od porodní bolesti, jako je právě VR (9). Výsledky naznačují, že klinické využití virtuální reality může snížit 
horší prožívání porodní bolesti během porodu, oproti rodičkám, které využili farmakologické metody. Následně poukazují na možnost využití nové metody VR jak v porodnictví, tak i v gynekologii (14). Hlavním př́nosem literární review je změna a posun společenských norem při poskytování péče v porodnictví za pomoci využití nových metod a moderní technologie $\mathrm{v}$ péči o ženy s porodní bolestí. Výsledky by měly vést ke zkvalitnění poskytované péče a spokojenosti žen se samotným těhotenstvím a porodním procesem. Práce poslouží $\mathrm{k}$ realizaci studie využití virtuální reality $\mathrm{u}$ rodících žen $\mathrm{v}$ české klinické praxi.

\section{VÝSTUPY}

Kvalitativní literární review zkoumající využití virtuální reality jako nefarmakologické metody pomáhající zvládat porodní bolest poukazuje na nové možnosti při péči o rodící ženy. V současné době v české klinické praxi neexistují žádné výzkumu, jež by se podobnou problematikou zabývaly. Také zahraniční studie zabývající se využitím virtuální reality VR v porodní asistenci není př́liš mnoho. $\mathrm{Z}$ toho důvodu se chceme více zaměřit na využití virtuální reality jako nefarmakologické metody $\mathrm{v}$ porodní asistenci $\mathrm{v}$ naší klinické praxi. Literární review poslouží $\mathrm{k}$ prrípravě pilotní studie a argumentaci využití VR jako nefarmakologické metody $\mathrm{v}$ péči o rodičky s porodní bolestí v české klinické praxi. Tyto pokroky v technologii nám mohou potenciálně otevř́t nové možnosti v porodnictví, jež je třeba zvážit při péči o rodící ženy, ale $\mathrm{i}$ třeba $\mathrm{v}$ dalších oblastech $\mathrm{v}$ porodnictví a gynekologii. Díky vývoji techniky a dalším možnostem můžeme vidět, že péče v porodní asistenci se neustále vyvíjí a je výzvou, jak pro teoretiky $\mathrm{v}$ ošetřovatelství $\mathrm{v}$ porodní asistenci, tak i praxi. Výsledky by mohly být využity také $\mathrm{v}$ oblasti vzdělávání zdravotnického personálu pečující o rodící ženy.

Mezi limity tohoto přehledového článku můžeme pokládat zařazení pouze publikací anglickém jazyce a vyhledávání článků pouze $\mathrm{z}$ dostupných elektronických informačních zdrojů autorů.

\section{Etické aspekty a konflikt zájmu}

Deklaruji, že výzkumné šetření v rámci přehledové literární review nemá žádný konflikt zájmu a při pracovávání výsledků byly dodrženy veškeré etické aspekty.

\section{REFERENČNÍ SEZNAM}

1. Frey D, Bauer M, Bell LC, Low LK, Hassett A, Cassidy RB et al. Virtual Reality Analgesia in Labour: The VRAIL Pilot Study - A Preliminary Randomized Controlled Trial Suggesting Benefit of Immersive Virtual Reality Analgesia in Unmedicated
Laboring Women [Internet]. 2019 [cited 2019 Jun 1];128(6)[e93-e96 p.]. Available from: https:// pubmed.ncbi.nlm.nih.gov/31094789/.

2. Acog - American College of Obstetricians and Gynecologists. Approach to Limit Intervention During Labor and Birth [Internet]. 2018 [cited 2019 Dec 12]. Available from: https://www.acog. org/clinical/clinical-guidance/committee opinion/ articles/2019/02/approaches-to-limit-intervention-during-labor-and-birth.

3. Mander R. Těhotenství, porod a bolest. Praha: Triton; 2014.

4. Jessamyn C, Evans JB, Hong D, Shafer S. The Development and Validation of a Dynamic Model to Account for the Progress of Labor in the Assessment of Pain [Internet]. 2008 [cited 2008 May 5];106(5):[1509-1515 p.]. Available from: https://www.researchgate.net/publication/5431575_ The_Development_and_Validation_of_a_Dynamic_Model_to_Account_for_the_Progress_of Labor_in_the_Assessment_of_Pain.

5. Málek J et al. Léčba pooperační bolesti. Praha: Mladá Fronta; 2009.

6. Bašková M. Metodika psychofyzické prrípravy ženy na porod. Praha: Grada Publishing, a.s.; 2015

7. Lowe N. Self-efficacy for labor and childbirth fears in nulliparous pregnant women. Journal of Psychosomatic Obstetrics Gynecology [Internet]. 2000 [cited 2000 Dec 8];21(4):[2019-2024 p.]. Available from: https://pubmed.ncbi.nlm.nih. gov/11191169/.

8. Raudenská K et al. Strach související s porodní bolestí. Praha: Univerzita Karlova; 2014.

9. Roberts L, Gulliver B, Fisher J, Cloyes KG. The coping with labor algorithm: an alternate pain assessment tool for the laboring woman. Journal of Midwifery Women's Health [Internet]. 2010 [cited $2010 \mathrm{Mar}-\mathrm{Apr}$; 55(2):[107-116 p.]. Available from: https://pubmed.ncbi.nlm.nih.gov/20189129/.

10. Cowles SD, Norton TJ, Hannafort KL, Foley M. Virtual reality may decrease pain during labor. American Journal of Obstetrics \& Gynecology [Internet]. 2019 [cited 2019 May 5];220(1):[S527-S528 p.]. Available from: https://journals.lww.com/greenjournal/Abstract/2019/05001/Virtual_Reality_ for_Pain_Control_During_Labor_.717.aspx.

11. Ebrahimzadeh ZS, Nahid JS, Nahvi A, Seyed RM, Nahid G, Mahdi T, et al. The Effect of Virtual Reality on Pain in Primiparity Women during Episiotomy Repair: A Randomize Clinical Trial. Iranian Journal of Medical Sciences [Internet]. 2015 [cited 2015 May 5];40(3):[2019-2024 p.]. Avail- 
able from: https://www.ncbi.nlm.nih.gov/pmc/ articles/PMC4430883/.

12. Koyyalamudi V, Sidhu G, Cornett EM Nguyen V, Brown CL, Fox CHJ et al. New Labor Pain Treatment Options. Current Pain and Headache Reports [Internet]. 2016 [cited 2016 Jan 16];20(2):[11 p.]. Available from: https://pubmed.ncbi.nlm.nih. gov/26780039/.

13. Triberti S, Repetto C, Riva G. Psychological Factors Influencing the Effectiveness of Virtual RealityBased Analgesia: A Systematic Review. Cyberpsychology, Behavior, and Social Networking [Internet]. 2014 [cited 2014 Jun 3];17(6):[335-345 p.]. Available from: https://pubmed.ncbi.nlm.nih. gov/24892195/.

14. Montano Z, Li A, Chen VJ, Gold JI. Virtual reality and pain management: Current trends and future directions. Pain Management [Internet]. 2011 [cited 2011 Mar 2];1(2):[147-157 p.]. Available from: https://www.ncbi.nlm.nih.gov/pmc/ articles/PMC3138477/.

15. Karlsdottir S, Lundgren I, Halldorsdottir S. The third paradigm in labour pain preparation and management: the childearing woman's paradigm. Scandinavian Journal of Caring Sciences [Internet]. 2014 [cited 2014 June 1];28(2):[3015-3027 p.]. Available from: https://www.researchgate.net/publication/244479461_The_third_paradigm_in_labour_pain_preparation_and_management_The childbearing_woman's_paradigm.

16. Pavlíková M. Analýza dat o rodičkách z registru národního referenčního centra. [Internet]. 2015 [cited 2016 Aug 6]. Available from: https://www. biostatisticka.cz/analyza-dat-nrc- $0 /$.

\section{KORESPONDUJÍCÍ AUTOR}

Mgr. Eva Puhlová

Fakulta zdravotnických studií

Univerzita Jana Evangelisty Purkyně

v Ústí nad Labem

Katedra porodní asistence a specifických disciplín Velká Hradební 13, Ústí nad Labem, 40003

Email: eva.puhlova@ujep.cz

Tel: 776778179 